\title{
TATA KELOLA DAN PENINGKATAN DAYA SAING EKONOMI: SUATU PENULUSURAN KONSEP
}

\author{
GOVERNANCE AND IMPROVEMENT OF ECONOMIC \\ COMPETITIVENESS: A CONCEPT DEVELOPMENT
}

\author{
Maxensius Tri Sambodo \\ Peneliti Pusat Penelitian Ekonomi \\ Lembaga Ilmu Pengetahuan Indonesia \\ Widya Graha LIPI, Kav. 10 Lt 4-5, Jakarta Selatan, Indonesia \\ Maxensius.tri.sambodo@lipi.go.id; smaxensius@yahoo.com
}

\begin{abstract}
Abstrak
Tulisan ini dimaksudkan untuk menganalisis keterkaitan antara tata kelola (governance) dengan daya saing. Governance perlu bercirikan pada karakteristik unggul yang dimiliki oleh para aktor ekonomi, yaitu pemerintah, pelaku usaha dan masyarakat baik dalam lokus global, pusat, dan deaerah. Karakteristik unggul merupakan hasil dari interaksi antara aspek proper governance yang mencakup developmentalist, democratic, socially inclusive dan local content dengan aspek daya saing yang mencakup trust and confidence; gradual, balance and specific; dan cooperative and collaborative. Operasional 'proper governance' dalam konteks daya saing diarahkan untuk memperkuat pembangunan yang inklusif dan bercirikan semangat pada kerja sama atau gotong royong.
\end{abstract}

Kata Kunci: tata kelola, daya saing, tata kelola yang pantas, inklusif, kerja sama

\begin{abstract}
This paper aimed to develop a conceptual framework that connect between governance and competitiveness. Governance needs to exploite and develop, supreme charactheristics of economic community within government, business sector, and society in the context of global, central and local government. We defined this framework as proper governance. Proper governance in the context of competitiveness aims to promote inclusiveness and cooperative. Proper governance is optimal combinations among elements of proper governance such as developmentalist, democratic, socially inclusve, and local content; and the elements of competitiveness such as trust and confidence, gradual, balance, and specific, and cooperative and collaborative. Thus, proper governance in the context of competitivenss needs to develop inclusive development within the spirit of cooperative or gotong royong.
\end{abstract}

Keywords: governance, competitiveness, proper governance, inclusive and cooperative

JEL: O01, P00 


\section{PENDAHULUAN}

Tata kelola pemerintahan yang baik (good governance) telah dijadikan sebagai 'kata kunci' (keyword) ataupun prasyarat bagi negara-negara berkembang untuk memperoleh akses pendanaan pembangunan dari lembaga donor. Namun, 'takaran' good governance yang diminta oleh lembaga donor, nampaknya kurang pas dengan kondisi riil yang dihadapi oleh banyak negara berkembang. Hal ini jugalah yang selanjutnya, membuka ruang bagi Grindle (2007) dan akademisi lainnya untuk memberikan moda 'alternatif' dari good governance (GG) yaitu good enough governance (GEG) (lihat Tabel 1). GEG dinilai jauh lebih pas dan kompromistis dengan kondisi riil yang dihadapi oleh banyak negara berkembang. GEG juga menuntut para pengambil kebijakan untuk berani melakukan penyesuaian (adjustment) atas standar capaian hasil pembangunan yang menjadi keinginan ataupun agenda dari negara maju ataupun lembaga-lembaga donor.

Tabel 1. Pilihan Kata dalam Diskurs Tata Kelola

\begin{tabular}{|l|l|}
\hline $\begin{array}{l}\text { Good } \\
\text { governance }\end{array}$ & $\begin{array}{l}\text { Good enough governance (Grindle } \\
\text { 2004; 2007) }\end{array}$ \\
\hline $\begin{array}{l}\text { The First-Best } \\
\text { Practice }\end{array}$ & $\begin{array}{l}\text { The Second Best Practice (Rodrik } \\
\text { 2006) }\end{array}$ \\
\hline Optimal & Sub-optimal governance \\
\hline Root & Branch (Lindblom 1959) \\
\hline & Satisficing (Simon 1957) \\
\hline & Ladderwise (Chang 2002) \\
\hline & Incremental governance \\
\hline & Stepwise governance \\
\hline
\end{tabular}

Sumber: Kim (2010: 291, tabel 3)

Artikel ini dimaksudkan untuk mendalami bagaimana governance berinteraksi dengan daya saing (competitiveness). Sistematika penulisan terbagi dalam enam bagian. Setelah pendahuluan, bagian dua membahas konsep dasar daya saing. Bagian tiga mengupas konsep good governance dalam mendukung peningkatan daya saing ekonomi. Bagian ke empat berisikan analisis terkait dengan kekuatan dan kelemahan atas konsep good governance dalam konteks daya saing ekonomi. Bagian kelima merupakan rekonstruksi konsep good governance untuk mendukung peningkatan daya saing; dan bagian terakhir ditutup dengan aplikasi konsep.

\section{TINJAUAN PUSTAKA}

\section{Konsep Daya Saing}

Sebelum mengkaji lebih dalam tentang daya saing, maka penting untuk mengupas lebih dulu faktor-faktor yang diyakini sebagai penyebab banyak negara menjadi kaya. Dengan berkaca dari pengalaman Taiwan dan Korea Selatan, Rodrik (1995) memberikan penjelasan akan kemajuan Taiwan dan Korea Selatan sebagai berikut:

"On the top, was required was a competent, honest and efficient bureaucracy to administer the interventions, and a clear-sighted political leadership that consistently placed high priority on economic performance" (Rodrik, 1995: 91).

Petikan tersebut menggarisbawahi bahwa Rodrik menekankan akan pentingnya birokrasi sebagai intervening variable yang mampu menghantarkan perekonomian menuju kinerja terbaiknya atau lebih berdaya saing. Rodrik menekankan pentingkan sisi birokrasi yang efektif sebagai berikut:

"I will argue that in the early 1960s and thereafter the Korean and Taiwanese governments manged to engineer a significant increase in the private return to capital. They did so not only by removing a number of impediments to investment and establishing a sound investment climate, but more importantly by alleviating a coordination failure which have had blocked economic take-off. The latter required a range of strategic interventions-including investment subsidies, administrative guidance and the use of public enterprise-which went considerably beyond those discussed in the standard account. That government intervention could play such a productive role was conditioned in turn by a set of advantageous initial conditions: namely, a favourable human capital endowment and relativey equal distribution of income and wealth" (Rodrik, 1995: 57).

Forum Ekonomi Dunia atau World Economic Forum (WEF) menghasilkan laporan tentang 
indeks daya saing global (global competitiveness index). WEF mendefinisikan daya saing sebagai meningkatnya produktivitas suatu negara. Daya saing tersebut ditentukan oleh kesatuan atas tiga komponen besar kelembagaan, kebijakan, dan faktor-faktor input (lihat Gambar 1). WEF melihat kelembagaan sebagai kerangka hukum dan administrasi (legal and administrative framework). Lebih jauh WEF juga berpendapat, institusi mencakup area yang lebih luas dari sekedar kerangka hukum (legal framewok). Sikap pemerintah terhadap pasar dan kebebasan, serta efisiensi atas kerja pemerintah juga sangatlah penting. Jika ditelisk lebih jauh maka sikap pemerintah masuk dalam lingkup tata kelola dan reformasi birokrasi. Dengan demikian, menjadi jelas daya saing ekonomi tidak dapat dilepaskan dari kondisi tata kelola pemerintah.

WEF juga menekankan akan pentingnya tata kelola di sektor swasta atau korporasi. Dalam tataran yang lebih mikro, (Griffiths, dkk. 2005) menyampaikan dua pendekatan utama dalam menjelaskan variasi daya saing industri yaitu: (i) manajemen strategis (strategic management) yang bersifat firm centric dan ekonomi politik (political economy) yang bersifat (state centric).
Kondisi ini kembali mempertegas bahwa daya saing tidak hanya berada di ranah atau tanggung jawab negara, namun juga perusahaan. Bahkan (Griffiths dkk. 2005) mengatakan dalam kondisi persaingan global yang dinamis atau kondisi persaingan yang terus berubah, sistem tata kelola yang mengkombinasikan tata kelola perusahaan dan pemerintah akan memberikan kemampuan lebih baik untuk melakukan adaptasi secara cepat.

Tentu saja studi daya saing tidak hanya dilakukan oleh World Economic Forum (WEF), lembaga lainnya seperti Harvard Institute for International Development (HIID), Heritage Foundation (HF), Fraser Institute of Vancouver (FI), dan International Institute for Management Development (IMD) juga melakukan hal yang sama (Giap 2004). Giap (2004) mengaplikasikan metodologi dari World Competitiveness Yearbook (WCY), Giap fokus pada empat dimensi daya saing yaitu: (i) lingkungan ekonomi; (ii) lingkungan politik; (iii) lingkungan bisnis; dan (iv) lingkungan sosial. Selanjutnya dari kempat lingkungan tersebut, dibagi kembali ke dalam beberapa kriteria dan total yang terkumpul sebanyak 122 kriteria. Hasil studi dari Giap (2004) menunjukkan baik Indonesia, Cambodia, dan

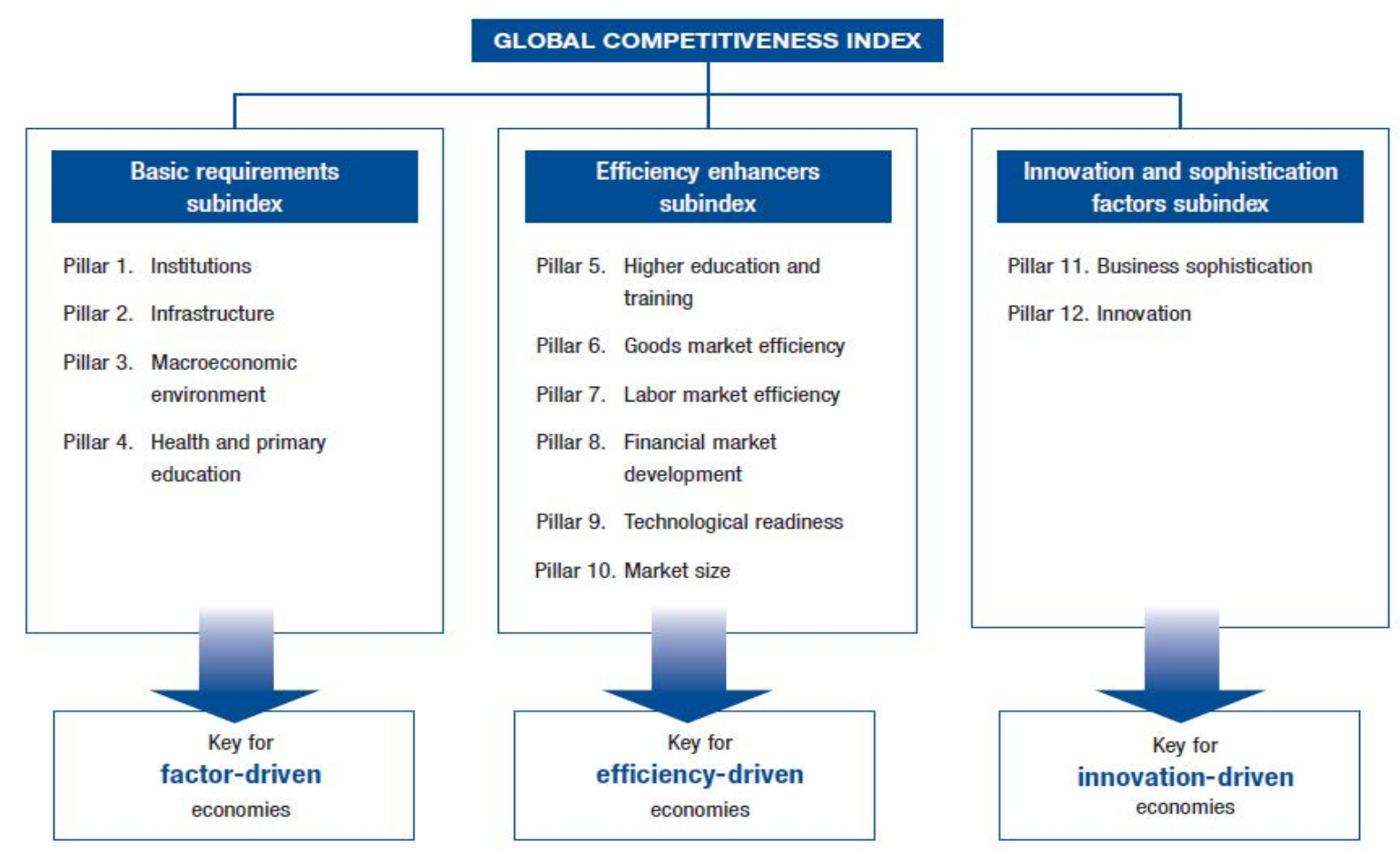

Sumber: World Economic Forum(2017)

Gambar 1. Kerangka Indeks Daya Saing Global 
Lao PDR diklasifikasikan sebagai negara dengan perekonomian lemah (weak economies).

\section{METODE PENELITIAN}

Penelitian ini menggunakan pendekatan kualitatif. Menurut Yusuf (2015), peneliti kualitatif berusaha mencari makna, pemahaman, pengertian, verstehen tentang suatu fenomena, kejadian, maupun kehidupan manusia dengan terlibat secara langsung dan/atau tidak langsung dalam setting yang diteliti, kontekstual dan menyeluruh. Yusuf (2015), juga mengatakan, penelitian kualitatif merupakan suatu strategi inquiry yang menekankan pencarian makna, pengertian, konsep, karakteristik, gejala, simbol, maupun deskripsi tentang suatu fenomena, fokus dan mutimetode, bersifat alami dan holistik, mengutamakan kualitas, menggunakan beberapa cara, serta disajikan secara naratif.

\section{HASIL DAN PEMBAHASAN}

\section{Konsep Dasar Good Governance Dalam Mendukung Peningkatan Daya Saing Ekonomi}

Analisis pada bagian sebelumnya menunjukkan bahwa birokrasi dan tata kelola pemerintahan memegang peranan sentral dalam menjelaskan kemajuan ekonomi dan daya saing suatu negara. Para ekonom yang mendalami sejarah telah menyadari bahwa perbedaan dalam hal tata kelola dan institusi (governance and institutions) menjadi faktor penjelas penting terjadinya inovasi bahkan revolusi industri (Olson, dkk., 2000). Selanjutnya Olson, dkk (2000), mencari penjelas lain bagi pelengkap teori pertumbuhan neoklasik (neoclassic theory) dan endogenous growth theory. Olson, dkk (2000) berpendapat kualitas tata kelola (quality of governance) memegang peranan kunci dalam dalam menganalisis pertumbuhan ekonomi. Dalam analisisnya, Olson., dkk (2000) memilih beberapa variabel yang terkait erat dengan governance seperti: (i) risiko bagi perusahaan asing untuk disingkirkan atau dinasionalisasi (risk of expropriation); (ii) risiko pemerintah untuk merubah kontrak yang telah disepakati (riks of repudiantion); (iii) korupsi di pemerintahan; (iv) kualitas birokrasi; dan (v) aturan hukum. Analisis Olson, dkk (2000) menunjukkan struktur insentif yang mendorong aktivitas para pelaku usaha menjadi determinan penting bagi kinerja ekonomi. Namun struktur insentif sangat tergantung pada kualitas tata kelola.

Temuan Olson dkk (2000), nampaknya tidak jauh berbeda dengan studi sebelumnya yang dilakukan oleh North (1994:359) yang mengatakan "in the analysis of economic performance thorugh time it contained two errorneous assumptions: (i) that institutions do not matter and (ii) that that does not matter." Selanjutnya North (1994:359360) juga mengatakan:

Institution forms the incentive structure of society, and the political and economic institution, in consequence, are the underlying determinants of economic performance. Time as it relates economic and societal change is the dimension in which the learning process of human being beings shapes the way institutions evolve.

North (1994:360) mendefinisikan institusi sebagai 'the humanly devised constraints that structure of human interaction". Institusi tidak hanya berupa aturan formal, namun juga informal yang memiliki ciri penegakkan (enforcement). Lebih jauh hubungan antara institusi dengan daya saing dikatakan sebagai berikut (North, 1994:360): "Institution and the tehnology employed determined the transaction cost and transformation cost that add up to the costs of production." Merujuk pada alur pemikiran North (1994), maka ada dua implikasi yang dapat diberikan. Pertama, institusi bukanlah suatu konsep yang statis, baik aturan formal dan informal sangat mungkin untuk berubah mengikuti kebutuhan yang berkembang. Kondisi ini secara implisit menunjukkan adanya aspek pembelajaran atau spekturum gradualism. Kedua, biaya transaksi (transaction cost) merupakan variabel antara (a link in a chain dan an integrating construct) yang menghubungkan bagaimana institusi dan produksi saling berinteraksi. North (1994:361) mendefinisikan biaya transaksi sebagai berikut: "transaction costs are the costs of specifying what is being exchanged and of eforcing the consequent agreements". Sementara itu Kang (2003), melihat transaction costs dalam tiga komponen biaya yaitu: the cost of making, monitoring, dan enforcing agreements di antara para aktor. Selanjutnya, Brown dan Potoski (2003:443) mengatakan informasi dan kondisi ketidakpastian 
akan semakin memperbesar biaya transaksi: "the factors that give rise to transaction costs resuls from limited information and uncertainty".

Dengan demikian, jika dicermati, tata kelola yang baik (memberikan dampak positif bagi perbaikan kinerja ekonomi) adalah tata kelola yang mampu menurunkan biaya transaksi, menjaga hal milik (securing property rights), memberikan keterbukaan informasi, dan adanya jaminan hak hukum dan politik yang independen (judicial and political rights are immutable). Kang (2003) melihat bagaimana biaya transaksi di Korea Selatan, Filipina dan Indonesia mempengaruhi kenerja ekonomi. Kang (2003) menganalisis bagaimana cronyism dan pembuat kebijakan (policymaking), saling berinteraksi dalam menentukan biaya transaksi. Dalam pendekatannya Kang (2003) menggunakan pendekatan new institutional economics (NIE) yaitu bagaimana para perilaku berkerja sama secara kredibel. Kang (2003) menilai, hubungan antara pemerintah dan bisnis di Korea Selatan berada dalam kondisi 'mutual hostage situation' yang mampu menurunkan biaya transaksi; sementara di Fipilina dan Indonesia biaya transaksi justeru meningkat. Selanjutnya Kang (2003:454) mengatakan bahwa:

"The smooth functioning of markets is not simply a matter of getting policies, incentives, or prices right, but of public and private institutions that facilitate market exchange, from the legal system and a clear delineation of property rights, to the public provision of information, to informal institutions that build trust".

Perlu menjadi perhatian bahwa interaksi para aktor, tidak hanya didorong oleh satu insentif, namun juga oleh interaksi antara kekuasaan (power), materi atau penghargaan (material rewards), nilai, dan norma (Traxler dan Unger, 1994). Menimbang kondisi insentif yang bercampur, maka membuat klasifikasi tata kelola institusi (governance institutions) juga tidak mudah. Sehingga Traxler dan Unger (1994), membagi government institutions ke dalam lima kategori yaitu: pasar (market); perusahaan atau organisasi (firm or organization); negara (state); korporasi (corporatism); dan jaringan (networks). Lebih jauh, Traxler dan Unger (1994), menganalisis dampak atas governance institution terhadap daya saing, dengan membuat perbandingan di dua arena yaitu cross national dan cross sectoral.

Temuan Traxler dan Unger (1994) sangat menarik, misalkan terkait dengan industri baja, masalah tata kelola yang paling utama yaitu diperlukannya biaya investasi yang besar, pada sisi lain kondisi penjualan baja penuh dengan gejolak. Dengan demikian, dapat terjadi kondisi investasi berlebih (overinvestment). Guna mengatasi hal tersebut, pemerintah Jepang memiliki stategi yang berbeda dengan Amerika Serikat. Melalui MITI (The Ministry of International Trade and Industry) pemertintah Jepang membangun jaringan kerja (network) bersama perusahaan-perusahaan besar. Tujuan jaringan kerjasama ini untuk mengatur alokasi produksi antara perusahaan. Namun demikian, secara bertahap MITI membiarkan fungsi koordinasi ini berjalan secara otonom. Hal ini mendorong industri untuk melakukan strategi investasi jangka panjang dengan mengadopsi teknologi terkini. Sementara itu, kondisi berbeda terjadi di Amerika Serikat, masing-masing perusahaan menghadapi kondisi ketidakstabilan pasar. Dengan demikian orientasi mereka lebih pada urusan jangka pendek yaitu keuntungan jangka pendek, sementara dalam hal modernisiasi teknologi menjadi urusan kedua.

Jerman dan Amerika Serikat mendominasi industri permesinan dunia. Namun demikian, persaingan dari Jepang dan negara industri baru lainnya mulai mengancam posisi Jerman. Demikian pula telah terjadi pergeseran permintaan dunia dari mekanikal otonomatis menjadi model fleksibel yang dikendalikan oleh komputer. Perusahaan-perusahaan Jerman, melakukan adaptasi terhadap perubahan kondisi pasar, sedangkan perusahaan-perusahaan Amerika Serikat gagal melakukan penyesuaian. Perusahaan Amerika Serikat lebih memilik pada strategi minimisasi risiko (risk minimization), dengan strategi integrasi vertikal, membuat perusahaanperusahaan besar yang sangat kuat dalam hal spesialisasi dan standarisasi. Kondisi berbeda dengan perusahaan-perusahaan Jerman yang mengambil sikap untuk mengembangkan sistem 
tata kelola jaringan dan korpotatisme. Kondisi ini mendorong perusahaan saling melakukan kerjasama (interfirm cooperation) di area yang tidak bersaing (noncompetitive) seperti dalam hal transfer pengetahuan (know-how) dan pembangunan produk (product development). Demikian halnya dengan kerjasama antara perusahaan dengan universitas, kerjasama antar perusahaan, serikat pekerja, dan asosasi bisnis untuk pelatihan (vocational training). Akibatnya, pola respon industri di Jerman lebih pada distribusi risiko (risk distribution) dan eksternalisasi kepada agen-agen lainnya atau bukan pada internalisasi risiko (risk internalizing).

Bercermin pada contoh-contoh tersebut, Traxler dan Unger (1994), masuk pada suatu kesimpulan bahwa tata kelola kelembagaan yang bersifat corporatism dan network, lebih baik dari pasar, perusahaan dan negara. ${ }^{1} \mathrm{Hal}$ ini terlihat dari pernyataan berikut (Traxler dan Unger, 1994:15)

Corporatism and network are better than the market, the firms, or the state because they are able to optimize the conflicting requirements of flexibility and long-term orientation. This is because they combine the incetives of power, material rewards, and normative recognition in a more complex manner than the other governance institution. They incorporate private expected gains in that they are built on exchange relations, but without organizing them according to the strict rule of market competition.

Selanjutnya, Traxler dan Unger (1994:17) juga mengatakan:

Many comparative studies have shown that countries with could rely on corporatist-based economic policies were significantly more sucessul in the 1960s and 1970s than others in optimizing macroeconomic goals such as economic growth, price stability, and employment.

\footnotetext{
${ }_{1}^{1}$ Traxler dan Unger (1994) mendefinisikan corporatism sebegai berikut: "allocation and regulation occurs here through private association, wither autonomously or in cooperation with state agencies". Ketika berinteraksi dengan negara, maka tujuan utamanya yaitu penyediaan barang bersama (collective goods). Sementara itu network didefinisikan dalam beberapa nama seperti klan (clan), jariangan informal (in formal network), ataupun hubungan yang bersifat kontrak (obligational/rational contracting).
}

Apa yang yang dimaksud oleh Traxler dan Unger (1994) saat mengupas aspek corporatism, sebetulnya tidak jauh berbeda dengan apa yang dimaksud oleh Ansell dan Gash (2008) saat mendifinisikan tentang collaborative governance. Ansell dan Gash (2008:544) mengatakan: "A governing arrangement where one or more public agencies directly engage non-state stakeholders in a collective decision-making process that is formal, consensus-oriented, and deliberative and that aims to make or implement public policy or manage public programs or assets".

Pada sisi lain, Traxler dan Unger (1994) juga mengatakan permasalahan koordinasi dan komunikasi di antara para subsistem (ekonomi, pendidikan, ilmu pengetahuan dan politik), juga menjadi pendorong akan perlunya pendekatan corporatism-based. Hal ini karena, pendekatan corporatistm dan network dapat menjadi fungsi pengantar (intermediary) karena kedua pendekatan tersebut menciptakan kerangka untuk hubungan kerja sama (cooperative relations) di antara para aktor.

Selanjutnya, bagaimana konsep tata kelola dioperasionalisakan dalam konsep daya saing dikemukakan oleh Caudhuri dan Ray (1997) dimana analisis daya saing dapat dikelompokkan dalam tiga tingkatan yaitu: bangsa (nation), industri dan perusahaan. Namun demikian, sebagaimana dikemukan oleh Caudhuri dan Ray (1997), tingkatan ketiganya saling berhubungan dan tidaklah mutually exclusive. Misalkan saja, suatu perusahaan memiliki beberapa produk dan unit bisnis, entitas tersebut merupakan bagian dari suatu industri dan tentu saja merupakan bagian dari lingkungan nasional yang memiliki sejarah yang unik, institusi dan warisan budaya (Caudhuri dan Ray, 1997). Caudhuri dan Ray (1997:M-90) juga mengatakan:

Thus other than intraorganisational characteristics competitivenss of a firm depends critically on a variety of external factors such as government policies, institutional and industry structure, availability of factors such as finance and information, cultural hetitage of the nation, interorganisational linkages with other firms and with supporting institutions such as R and D laboratories, etc. Involvement 
of so many variables makes the subject of competitiveness extremely complex.

\section{Kekuatan Dan Kelemahan: Suatu Kritik Terhadap Konsep Good Governance Pada Konteks Daya Saing Ekonomi}

Analisis pada bagian sebelumnya menunjukkan bahwa lokus daya saing dapat berada dalam tingkat yang berbeda. Demikian, juga terlihat adanya perbedaan titik berat dalam hal aktor yang secara aktif dapat menggerakan daya saing mulai dari melihat peran negara (state), hingga collaborative governance. Hal ini menunjukkan, adanya relatifitas dalam hal lokus dan aktor dalam memacu daya saing. Aktor yang belum banyak disinggung yaitu komunitas atau kelompok. Menyerahkan daya saing dalam ranah negara dan pasar, belumlah memadai. Dalam transisi menuju masyarakat yang lebih demokratis, komunitas dapat mengambil peran penting dalam mengerakan roda ekonomi. Peran komunitas, juga diakui dalam bentuk diakuinya hak-hak komunitas (community rights) sebagaimana banyak dikaji oleh Elinor Ostrom yang mendapatkan hadiah nobel untuk karya-karya di bidang tata kelola dan komunitas.

Pengalaman Malaysia sebagaimana dikemukakan oleh Siddiquee dan Mohamed (2007), menunjukkan reformasi dan meningkatnya menajemen serta pelayanan hanya memberikan pengaruh kecil terhadap perbaikan tata kelola yang baik. Hal ini terjadi karena tiga faktor. Pertama, reformasi masih dilakukan secara terbatas dan belum dapat dukungan reformasi pada sektor lainnya seperti yang halnya terjadi di sistem politik dan pemerintahan. Kedua, pola kepemimpinan yang eksklusif atau bahkan cenderung diktaktorial seperti dikatakan oleh Siddiquee dan Mohamed (2007: 309): "As the political leadership is keen to retain and strengthen its control over the society rather than weaken it through reforms, it has shied away from reforms in areas of decentralisation of power, democratization of administration and grassroots participation". Ketiga, belum terbangunnya tata kelola yang inklusif sebagaimana dikatakan sebagai berikut: "Although the government's policy of favoring effective governance over good governance has arguably worked well in that it helped maintain order and stability in the society thereby facilitating steady economic growth in past decades, the crisis of the late 1990s has demonstrated that economic growth is difficult to sustain in the absence of broadly inclusive good governance."

Maksud dari inclusive good governance yaitu tata kelola yang memperhatikan kepentingan semua unsur di dalam masyarakat secara berimbang sebagaimana disampaikan oleh Siddiquee dan Mohamed (2007: 309) sebagai berikut: "Since the public service in Malaysia is an important element in the institutionalization of Bumiputra advantages and privileges in return for their loyalty and support (Cheung, 2001), those within the administration have no reasons to support the reforms that will jeopardize such privileges."

Kim (2010) mengatakan tata kelola penting untuk membangun rasa percaya dan keyakinan (trust and confidence). Akan tetapi, membangun kedua hal tersebut bukanlah hal yang mudah bagi negara berkembang karena negara berkembang memiliki banyak kendala. Tata kelola merupakan suatu proses yang kompleks, ia tidak hanya terikat pada dimensi kelembagaan formal, informal namun juga pada perilaku para aktor. Aspek perubahan perilaku tentu saja memerlukan waktu. Dengan demikian, sangat tepat argumentasi North (1994), bahwa dalam mengkaji kinerja perkonomian, aspek kelambagaan dan waktu merupakan asumsi terpenting yang harus diperhatikan. Dengan demikian, tata kelola idealnya diapresiasi sebagai suatu proses pembelajaran yang bersifat gradual dalam menuju sasaran yang ditetapkan. North (1994) mengatakan, tingkat pembelajaran akan tergambarkan dari intensitas persaingan antar organisasi. Selanjutnya, persaingan terjadi karena adanya kelangkaan sumber daya yang terjadi secara global. Kondisi ini akan mendorong lembaga-lembaga untuk terlibat dalam proses pembelajaran agar mampu bertahan (North, 1994). Dengan demikian, Kim (2010) menyarankan agar negara lebih fokus pada hal-hal yang dapat dilakukan dan dicapai (berorientasi pragmatis). Sebagai pendekatan alternatif, Kim (2010) mengusulkan konsep "middle ground" yang mencirikan pentingnya kepemimpinan. Hal ini terlihat pada petikan berikut (Kim, 2010: 294): 
"Instead of utilizing short sighted political maneuvering or tactical political engineering, top leader's genuine willingness also becomes a higly critical matter for pursuing sustainable development in addition to economic growth and governance reform in developing countries."

Masih terkait dalam langkah mencari solusi yang pragmatis, Mamoon dan Murshed (2006) menggarisbawahi bahwa kualitas institusi dan pembangunan institusi adalah fenomena jangka panjang, dan sulit berubah oleh kebijakan yang bersifat jangka pendek. Dengan melakukan uji empiris atas kebijakan perdagangan dan kebijakan industri, Mamoon dan Murshed (2006:108) menyimpulkan:

“...trade policies matter and substantiates the earlier studies regarding the importance of trade policy in determining economic growth. Trade policies are far less systematic than other policy, such as those with regard to the domestic industrial structure (subsidies the state owned enterprises, say)..."

Penting untuk dipahami bahwa mendudukan konsep tata kelola dan daya saing bukanlah hal yang mudah. Sebagaimana telah disinggung pada bagian sebelumnya, perdebatan tentang konsep tata kelola masih terus berkembang. Demikian pula dengan daya saing (competitivenss). Chaudhury dan Ray (1997) menyimpulkan bahwa daya saing merupakan konsep yang kompleks, multidimensi dan bersifat relatif. Sehingga, upaya mendefinisikan daya saing sendiri merupakan suatu masalah penelitian (Chaudhury dan Ray, 1997). Namun demikian upaya untuk mendorong pemahaman dan memfasilitasi perkembangan subjek daya saing, dapat dilakukan jika telah terbangun kejelasan dalam hal definisi, unit analisis, variabel-variabel yang akan diteliti, dan tingkatan dimana isu tersebut akan diteliti.

Demikian pula, walaupun pada bagian sebelumnya disinggung collaborative governance institution memiliki banyak keunggulan dibandingkan dengan instution governance lainnya, namun Ansell dan Gash (2008: 561), mengatakan:"...the problems that collaborative startegies encounter as they pursue the valued outcomes: powerfull stakeholders manipulate the process; public agencies lack real commitment to collaboration; and distrust becomes a barrier to good faith negotiation".

Dalam perkembangannya, Nanda (2006) mengemukakan bahwa ada tiga kelemahan dalam menjadikan good governance sebagai 'standard' untuk menghukum ataupun memberikan insentif bagi negara-negara berkembang. Pertama, good governance menjadi tidak efektif karena ini menjadi suatu bentuk 'conditionality' yang berimplikasi pada 'transfer sovereignty' yang memperlemah proses politik yang terjadi di tingkat domestik. Kedua, good governance merupakan suatu proses, dengan demikian, nampaknya kurang pas jika hal ini dijadikan landasan untuk memberikan bantuan, terlebih jika negara berkembang baru saja lepas dari regim pemerintah yang otoriter atau pemerintahan yang lemah. Ketiga, belum ada konsep atau standar yang jelas akan good governance, apalagi konsep yang ada cenderung mengabaikan konteks budaya dan sejarah.

Selanjutnya, indikator Worldwide Governance Indicators (WGI) secara meluas sudah digunakan. WGI mencakup enam 96) dimensi tata kelola yaitu: pendapatan/suara dan akuntabilitas; stabilitas politik dan ketiadaan kekerasan; efektivitas pemerintahan, kualitas regulasi, aturan hukum, dan pengendalian korupsi. Namun demikian konsepsi WGI yang telah dibangun oleh Bank Dunia tidak terlepas dari tiga permasalahan (Apaza 2009). ${ }^{2}$ Pertama, informasi yang dikumpulkan dalam WGI berdasarkan pada presepsi. Sehingga kondisi akurasi untuk mengukur tata kelola juga perlu dipertimbangkan. Kedua, dalam pemilihan konsep umum misalkan tentang korupsi, kemungkinan tidak dapat menangkap persepsi khusus di suatu negara. Sehingga (Apaza 2009) beragumentasi bahwa WGI belum dapat memberikan arahan yang jelas atas dimensi korupsi seperti sisi adminsitratif dari

\footnotetext{
${ }^{2}$ WGI terdiri atas enam komponen yaitu: 1) penyampaian pendapat dan pertanggungjawaban (voice and accountability), 2) stabilitas politik dan ketiadaan kerusuhan/terorisme (political stability and absence of violence/terrorism), 3) pemerintahan yang efektif (government effectiveness), 4) kualitas peraturan (regulatory quality), 5) aturan hukum (rule of law), dan 6) pengendalian atas korupsi (control of corruption.
} 
korupsi politik. Ketiga, kondisi riil dari setiap negara haruslah dicermati dan dipahami secara baik, misalkan terdapat hubungan positif antara kualitas regulasi dengan pemerintahan yang efektif. Akan tetapi situasi demikian mungkin tidak merefleksikan kondisi riil negara. Merujuk pada catatan Apaza (2009), maka ada dua kerentanan yang pelu diperhatikan dalam melihat kondisi good governance. Pertama, dengan basis pendekatan presepsi, maka penilaian akan bersifat situasional dan subjektif atau juga bisa dikatakan syarat dengan kepentingan, khususnya agenda para pemilik modal. Kedua, kesiapan regulasi akan menentukan seberapa cepat dan disiplin, proses menuju good governance dapat dicapai.

Pada sisi lain, Weymouth dan Feinberg (2011) menekankan akan perlunya kejelasan dalam mengaplikasikan terminologi daya saing (competitiveness) terutama ketika membuat pernyataan tingkat daya saing nasional secara keseluruhan, yaitu ketika kualitas lingkungan kelembagaan suatu negara diperbandingkan dengan negara lainnya. Weymouth dan Feinberg (2011: 155) juga mengingatkan “...country size and wealth are not particularly good proxies for the "quality" of the institutional environment, as the relationship between these variables and competitiveness appears to depend crucially on the particular conceptualization of competitiveness."
Lebih jauh Csath (2007:101) memberikan analisis kritisnya akan daya saing: "Finally we can pose a novel question for further investigation: should we talk about competitiveness, or rather about something elase, like fitness? Competitivensss represents the value of aggressiveness, hostility, win and lose situation. Fitnerss is about long term survival, co-operation, co-evolution and co-development." Selanjutnya Csath (2007) memberikan dua opsi kebijakan ekonomi berbasis daya saing (Tabel 2).

\section{Rekonstruksi Konsep Good Governance Untuk Mendukung Peningkatan Daya Saing Ekonomi}

Analisis pada tiga sub-bagian sebelumnya menunjukkan bahwa daya saing dapat didorong melalui suatu intervensi kebijakan. Kebijakan ekonomi merupakan ranah pemerintah atau birokrasi. Namun demikian kegagalan koordinasi (coordination failure) baik dalam tubuh pemerintah (state centric) ataupun antara pemerintah dengan perusahaan (state-firms centric) akan menjadi kontraproduktif untuk membangun daya saing. Lebih jauh untuk mengurangi kegagalan pemerintah, Krueger (1990), memberikan tiga tuntunan. Pertama, perlunya tuntunan spesifik atau kriteria atas kebijakan yang akan dilakukan termasuk perangkat adminstrasi yang diperlukan untuk mengimplementasikan kebijakan tersebut.

Tabel 2. Pilihan-Pilihan Kebijakan Ekonomi: Dua pendekatan daya saing dan konsekuensi

\begin{tabular}{|c|c|c|}
\hline Competition based on & Cheapness, quantity & Value, knowledge, quality \\
\hline People are & $\begin{array}{l}\text { Assembly operators } \\
\text { Hands and nerves } \\
\text { Servers }\end{array}$ & $\begin{array}{l}\text { Entrepreneurs } \\
\text { Co-workers } \\
\text { Citiens } \\
\text { Contributors, creators }\end{array}$ \\
\hline & Dependent & Independent \\
\hline Society is characterised by & $\begin{array}{l}\text { Lonely fighters } \\
\text { Win/lose relationship } \\
\text { Winner takes all society } \\
\text { situation }\end{array}$ & $\begin{array}{l}\text { Co-operative spirit } \\
\text { Win/win relationships }\end{array}$ \\
\hline & Low trust & Strong trust \\
\hline & Weak social capital & $\begin{array}{l}\text { Strong social capital, } \\
\text { cohesiveness }\end{array}$ \\
\hline Value & $\begin{array}{l}\text { The people serve the } \\
\text { economy }\end{array}$ & $\begin{array}{l}\text { The economy serves the } \\
\text { people }\end{array}$ \\
\hline Results are measured by & Profits, growth & Development, quality of life \\
\hline
\end{tabular}

Sumber: Csath (2007) 
Kedua, perioritas diberikan untuk kebijakan ataupun program yang membutuhkan input adminstrasi dan birokrasi yang minimum. Ketiga, pemerintah perlu memilih mekanisme yang kemungkinan kecil akan mendorong adanya rentseeking. Ketiga tuntunan yang disampaikan oleh Krueger dapat menjadi rujukan untuk menjawab pertanyaan dari Grindle yang disampaikan pada bagian sebelumnya yaitu: "What's essential and what's not?, What should come first and what should follow?, What can be achieved in the short term and what can only be achieved over the longer term?, What is feasible and what is not?"

Pertanyaan penting yaitu bagaimana pemerintah menentukan kriteria, tuntunan, standar, dan kapasitas untuk menjalankan kebijakan ekonomi yang akan mendorong daya saing? Posisi Indonesia yang sangat beragam dalam hal kondisi input, membuat pola kebijakan yang generik menjadi titik tengah untuk mengakomodasi diversitas yang ada. Namun, sayangnya, kerangka daya saing dilihat sebagai konsep yang 'head to head' atau 'one fit for all' agar dapat saling 'bertempur' di antara para aktor ekonomi. Padahal, dengan menerima adanya diversitas, pola yang lebih dikembangkan seharusnya lebih bersifat kerjasama (cooperation). Dengan demikian, daya saing idealnya dipandang sebagai buah dari dari suatu kerjasama. Paradigma, saling melengkapi dan kerjasama, idealnya menjadi basis untuk membangun daya saing nsional. Dengan demikian daya saing pelu didudukan dalam konteks persaingan yang inklusif dan bukan persaingan yang eksklusif atau saling meniadakan atau 'mematikan'.

Governance menjadi kunci untuk mewujudkan daya saing yang inklusif. Pemerintah dapat melakukan intervensi dan untuk mencapai intervensi yang berhasil Rodrik, dkk (1995:91) mensyaratkan beberapa kondisi: "On top, what was required was competent, honest and efficient bureaucracy to administer the interventions, and a clear-sighted political leadership that consistently placed high priority on economic performance". Dengan demikian, esensi dari good governance menuju ekonomi yang berdaya saing menghendaki adanya perubahan perilaku (behavior change) yang dilakukan dua semua aktor baik state, market dan society. Perubahan perilaku perlu dilakukan oleh semua tingkatan governance institutions. Perubahan perilaku akan termanifestasikan dalam bentuk penguatan rasa saling percaya (trust and confidence), kesetaraan dan keadilan (equality and fairness), kerjasama (collaborative governance) dan turunnya biaya transaksi (transaction cost).



Sumber: Ansell dan Gash (2008)

Gambar 2. Model Tata Kelola Kolaboratif (collaborative governance) 
Model tata kelola yang diusulkan oleh Ansell dan Gash (2008) dapat menjadi model awal untuk membangun proses kolaborasi yang inklusif (Gambar 2). Model tersebut menunjukkan bahwa tata kolola tersusun atas dimensi input, proses dan outcome. Aspek proses kolaborasi akan sangat berbeda antara negara, dan Indonesia sebetulnya sudah memiliki akar budaya yang kuat untuk membangun prinsip-prinsip kolaborasi kerjasama yang kuat seperti gotong royong dan kekeluargaan (jati diri bangsa). Kedua hal tersebut merupakan bagian dari nilai dan norma sebagaimana disebutkan oleh Traxler dan Unger (1994). Idealnya, dengan semakin berkembang teknologi informasi, komunikasi dan telekomunikasi, maka social network dapat lebih terkapitalisasi menjadi social capital.

Pola daya saing yang harus dibangun tidak hanya oleh dua kekuatan besar yaitu negara dan pasar, namun sisi modal sosial (social capital) telah melekat erat dalam komunitas masyarakat. Sehingga, daya saing yang inklusif dengan tata kelola yang bercirikan pada jati diri bangsa, menghendaki adanya keseimbangan di antara para aktor yaitu negara, masyarakat dan pasar untuk mewujudkan keadilan dan kesejahteraan sosial.

Elemen terpenting dari governance yaitu bagaimana mencirikan dan mengkapitaslisasi governance dengan karakteristik unggul yang ada di tingkat budaya para aktor (komunitas) ekonomi, yaitu pemerintah, pelaku usaha dan masyarakat baik dalam lokus global, pusat, dan deaerah. Membangun governance dalam konteks tersebut kami istilahkan sebagai 'proper governance'. Operasional 'proper governance' dalam konteks daya saing diarahkan untuk membangun daya saing yang lebih inklusif dan cooperative. Untuk sementara, matrik yang

Tabel 3. Derivasi Parameter Proper Governance untuk Daya Saing Ekonomi

\begin{tabular}{|c|c|c|c|c|}
\hline & \multicolumn{3}{|c|}{ Prinsip Daya Saing Ekonomi } \\
\hline & & Trust and confidence & $\begin{array}{l}\text { Gradual, balance and } \\
\text { specific }\end{array}$ & $\begin{array}{l}\text { Cooperative and } \\
\text { collaborative }\end{array}$ \\
\hline \multirow[t]{2}{*}{$\begin{array}{l}\text { proper } \\
\text { governance }\end{array}$} & Developmental & $\begin{array}{l}\text { State } \\
\text { 1. Stability } \\
\text { 2. Efficiency } \\
\text { 3. Transparency } \\
\text { 4. Competent } \\
\text { 5. Consistency } \\
\text { 6. Honesty } \\
\text { 7. Responsibility } \\
\text { Society } \\
\text { 1. Responsibility } \\
\text { 2. Solidarity } \\
\text { 3. Creativity } \\
\text { 4. Respect }\end{array}$ & $\begin{array}{l}\text { State } \\
\text { 1. No discrimination } \\
\text { 2. Neutral and broad based } \\
\text { intervention } \\
\text { 3. Free mobility of people } \\
\text { 4. Clear boundaries and } \\
\text { authorities } \\
\text { 5. Infrastructure promotion } \\
\text { Society } \\
\text { 1. Social network } \\
\text { 2. Social cohesion } \\
\text { 3. Social responsibility } \\
\text { 4. Empowerment and } \\
\text { enrichment }\end{array}$ & $\begin{array}{l}\text { State } \\
\text { 1. National resilence } \\
\text { 2. National sovereignty } \\
\text { 3. Environmental } \\
\quad \text { sustainability } \\
\text { Society } \\
\text { Community resilence }\end{array}$ \\
\hline & Democratic & $\begin{array}{l}\text { State } \\
\text { 1. Transparency } \\
\text { 2. Honesty } \\
\text { 3. Responsibility } \\
\text { 4. Accountability } \\
\text { 5. Leadership } \\
\text { 6. Law and order } \\
\text { 7. Due process of law } \\
\text { Society } \\
\text { 1. Freedom of expression } \\
\text { 2. Responsibility } \\
\text { 3. Respect }\end{array}$ & $\begin{array}{l}\text { State } \\
\text { 1. Fair competition and } \\
\text { profit/risks sharing } \\
\text { 2. Strengthening traditional } \\
\text { markets } \\
\text { 3. Ensuing mutual benefits } \\
\text { between modern and } \\
\text { traditional markets } \\
\text { Society } \\
\text { 1. Locally initiative driven } \\
\text { 2. Locally problem solving } \\
\text { driven }\end{array}$ & $\begin{array}{l}\text { State } \\
\text { 1. Protecting property } \\
\text { right } \\
\text { 2. State rights } \\
\text { Society } \\
\text { 1. Community rights } \\
\text { 2. Private rights }\end{array}$ \\
\hline
\end{tabular}




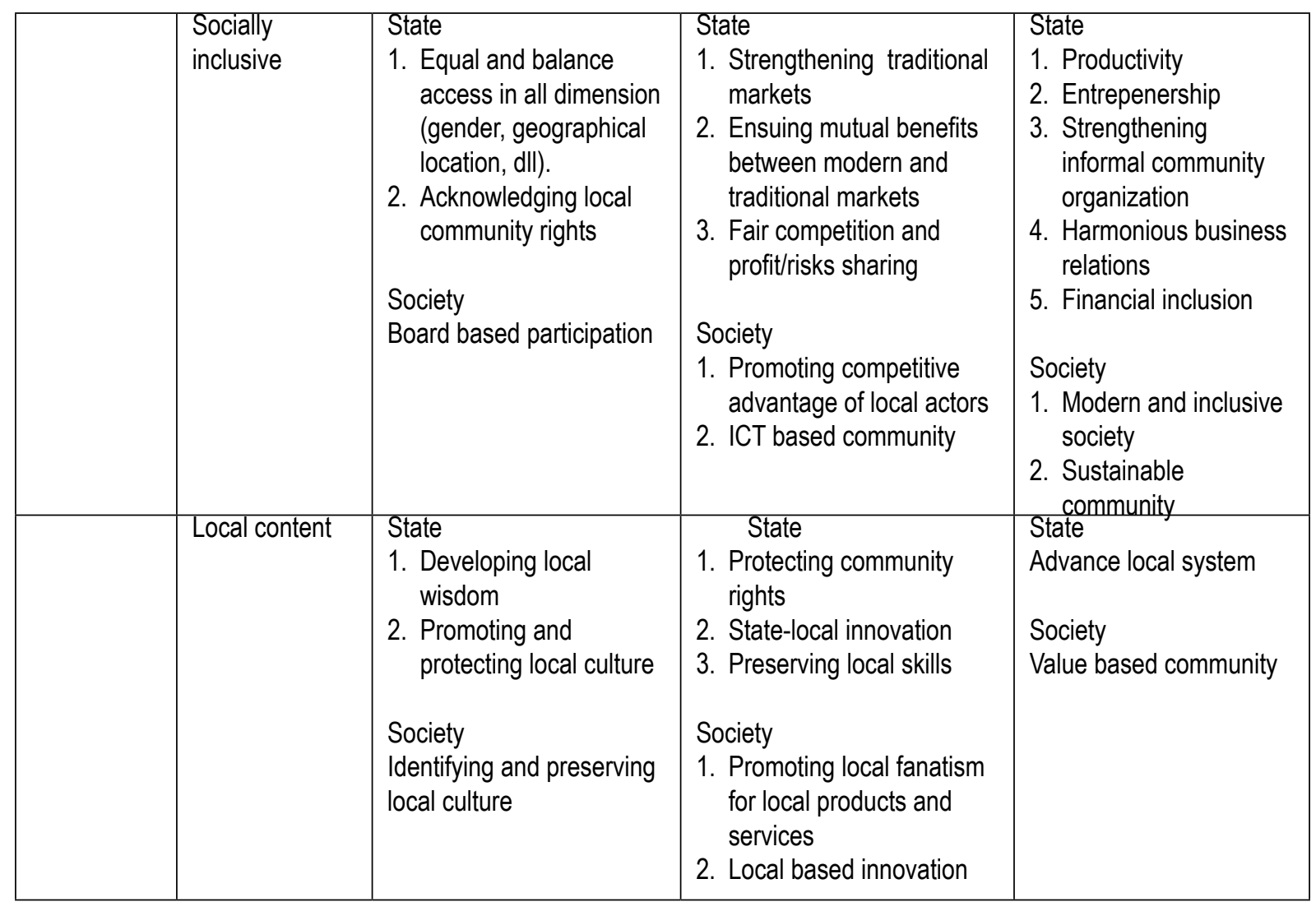

mencoba menghubungkan elemen-elemen daya saing dan proper governance, dipetakan dalam Tabel 3 Penjelasan yang terdapat dalam masing-masing sel, menggambarkan program ataupun kegiatan yang dapat dilakukan baik dalam tingkatan state dan society. Namun demikian, kedua aktor besar tersebut tersebut, bukanlah zona 'hitam putih'. Baik state dan society akan saling berinteraksi dalam suatu proses pembelajaran yang tentu saja membutuhkan waktu. Namun proses pembelajaran tersebut harus begerak dalam arah yang semakin baik untuk membangun masyarakat yang adil dan makmur.

Sejalan dengan, paradigm 'input-prosesoutput' yang dibangun dalam governance, maka daya saing, juga perlu diletakan dalam ketiga kerangka dasar secara objektif. Dengan pondasi atau input kepercayaan dan rasa percaya diri (trust and confidence), dalam proses transformasi yang bertahap, seimbang dan spesifik (gradual, balance and specific), maka akan terbangun kelembagaan dan organisasi yang berbasis kerjasama dan kolaborasi (cooperative and collaborative) (lihat Tabel 3)

\section{KESIMPULAN DAN SARAN}

Tabel 3 merupakan perpaduan akan prinsip proper governance and daya saing. Keduanya dapat diturunkan dalam tingkatan negara (state) dan masyarakat (society). Paremeter yang menjadi irisan merupakan hal-hal penting yang perlu menjadi fokus kebijakan. Misalkan, dalam aspek developmental yang beririsan dengan trust and confidence, peran negara (state), tertuju pada tujuh aspek yaitu: Stability, Efficiency, Transparency, Competent, Consistency, Honesty, dan Responsibility. Sementara itu pada tingkatan masyarakat maka perlu terus dibangun aspek: Responsibility, Solidarity, Creativity, Respect.

Tujuan negara untuk menjalankan kebijakan developmentalyaitu untuk mencapai pertumbuhan ekonomi, pemerataan, dan pemanfaatan sumber daya secara bertanggung jawab dan berkesinambungan. Namun demikian, idealnya kebijakan developmental perlu berprinsip pada ciri-ciri unggulan yang telah disebutkan tersebut. Sebagai contoh, kebijakan pemberian memberikan subsidi LPG merupakan pisau bermata dua terutama terkait dengan prospek jangka panjang. Melalui kebijakan ini tampak 
jelas, Negara mencoba untuk mengambil risiko jangka panjang dengan kebijakan 'subsidi LPG". Studi memperlihatkan kebijakan ini dapat menurunkan biaya melaut yang sangat berarti bagi nelayan kecil, dan penghematan tersebut digunakan baik untuk meningkatkan konsumsi ataupun untuk kegiatan produktif seperti untuk menambah modal kerja seperti pembelian jaring, dan sarana produksi lainnya. Kondisi ini menunjukkan sisi daya saing yang hendak dibangun.

Dimensi inklusifitas juga tampak dari kapasitas ekonomi penerima bantuan yang meningkat yang didukung oleh kegiatan konsumsi dan investasi. Dengan beralih dari penggunaan bahan bakar bensin ke bahan bakar gas (LPG) juga relatif lebih baik bagi lingkungan dalam hal pengurangan emisi karbon. Namun demikian, ada kekhawatiran ketimpangan antara masyarakat miskin maupun rentan miskin dengan masyakat mampu akan semakin melebar. Kebijakan subsidi komoditas akan lebih banyak dinikmati oleh kelompok masyarakat yang mampu. Jika kondisi ini terus dibiarkan tentu dapat menyebabkan prospek ketimpangan yang lebih besar di masa depan. Di samping itu, ada biaya kesempatan yang hilang akibat kebijakan subsidi, yaitu subsidi diberikan untuk hal-hal yang lebih produktif untuk meningkatkan kapasitas ekonomi secara merata di masa depan. Dengan demikian, dari sisi developmental, kebijakan ini sebetulnya menjadi boom waktu yang dapat memperlemah pembangunan yang berkeadilan di masa depan.

Jika negara dan masyarakat dapat saling mengembangkan nilai-nilai unggul yang dimiliki, maka bias-bias negatif kebijakan subsidi bisa dihindari. Desain kebijakan subsidi yang diarahkan untuk membantu masyarakat miskin perlu secara konsisten dijalankan oleh negara melalui tata kelola yang baik, sementera itu masyarakat sebagai lini terdepan terkait dengan implementasi program, dengan memegang prinsip-prinsip responsibility, solidarity, creativity, dan respect, perlu memastikan implementasi kebijakan tersebut berjalan seperti yang diharapkan.

Akhirnya, menu yang ditampilkan dalam Tabel 3 merupakan menu yang dinamis dan dapat diaplikasikan untuk berbagai rancangan kebijakan. Dengan memperhatikan peran yang optimal di masing-masing aktor, maka idealnya, tata kelola dan daya saing, merupakan dua hal yang bergerak untuk saling memperkuat pencapaian tujuan-tujuan pembangunan yang diharapkan yaitu masyarakat yang adil dan makmur. Masih terbuka lebar untuk mengembangkan kerangka yang disajikan dalam Tabel 3, bagi pendalaman berbagai studi kasus kebijakan ekonomi.

\section{DAFTAR PUSTAKA}

A'Gh, A. (2001). Public Sector Reforms, Institutional Design and Strategy for Good Governance in East Central Europe. Studies in East European Thought, 53 (3), 233-255.

Alence, R. (2004). Political Institutions and Developmental Governance in Sub-Saharan Africa. Journal of Modern African Studies, 42 (2), 163-187.

Apaza, Carmen R. (2009). Measuring Governance and Corruption through the Worldwide Governance Indicators: Critiques, Responses, and Ongoing Scholarly Discussion. Political Science \& Politics 42 (01), 139.

Ansell, C., dan Gash, A. (2008). Collaborative Governance in Theory and Practice. Journal of Public Administration Research and Theory: J-PART, 18 (4), 543-571.

Brown, T.L., dan Potoski, M. (2003). Transaction Costs and Institutional Explanations for Government Service Production Decisions. Journal of Public Administration Research and Theory: J-PART, 13 (4), 441-468.

Chaudhuri, S. dan Ray, S. (1997). The Competitiveness Conundrum: Literature Review and Reflections. Economic and Political Weekly, 32 (48), M83-M91.

Csath, M. (2007). The Competitiveness of Economies: Different Views and Arguments. Society and Economy, 29 (1), 87-102.

Giap, Tan Khee. (2004). The IPS-NTU ASEAN $9+1$ Economic Competitiveness Ranking Indices. Asean Economic Bulletin, 21(2), 234-38.

Griffiths, Andrew dan Raymond F Zammuto. (2005). Insitutional Governance System and Variation in National Competitiveness Advantage: An Integrative Framework. The 
Academy of Management Review, 30 (4), 823-42.

Grindle, M. (2007). Good Enough Governance. Development Policy Review, 25(5), 553-74.

Kang, D.C. (2003). Transaction Costs and Crony Capitalism in East Asia. Comparative Politics, 35 (4), 439-458.

Kim, Pan Suk. (2010). Building Trust by Improving Governance: Searching for a Feasible Way for Developing Countries. Public Administration Quarterly, 34 (3), 271-299.

Kruger, A. O. (1990). Government Failures in Development. Journal of Economic Perspectives, 4 (3), 9-23.

Mamoon, D. dan Murshed, S.M. (2006). Trade Policy, Openness, Institutions. The Pakistan Development Review, 45 (1), 99-119.

Nanda, V. P. (2006). The 'Good Governance' Concept Revisited. The ANNALS of the American Academy of Political and Social Science, 603 (1), 269-83.

North, D. (1994). Economic Performance through Time. American Economic Review, 84 (3).

Olson, M., Sarna, N., dan Swamy, A.N. (2000). Governance and growth: a simple hypothesis explaining cross-country differences in productivity growth. Public Choice, 102, 341-364.

Rodrik, D., Grossman, G., dan Norman, V. (1995). How South Korea and Taiwan Grew Rich. Economic Policy, 10 (20), 53-107.

Siddiquee, N.A. dan Mohamed, M.Z. (2007). Paradox of Public Sector Reforms in Malaysia: A Good Governance Perspective. Public Administration Quarterly, 31 (3/4), 284-312.

Traxler, F., dan Unger, B. (1994). Governance, Economic Restructuring, and International Competitiveness. Journal of Economic Issues, 28 (1), 1-23.

Weymouth, S. dan Feinberg, R. (2011). National Competitiveness in Comparative Perspective: Evidence from Latin America. Latin American Politics and Society, 53 (3), 141-159.

World Economic Forum. (2017). The Global Competitiveness Report 2017-2018. Diambil dari http:/www.weforum [diaskses 15 September 2017)

Yusuf, M. (2015). Metode Penelitia: Kuantitatif, Kualitatif \& Penelitian Gabungan. Jakarta: Prenadamedia Group. 